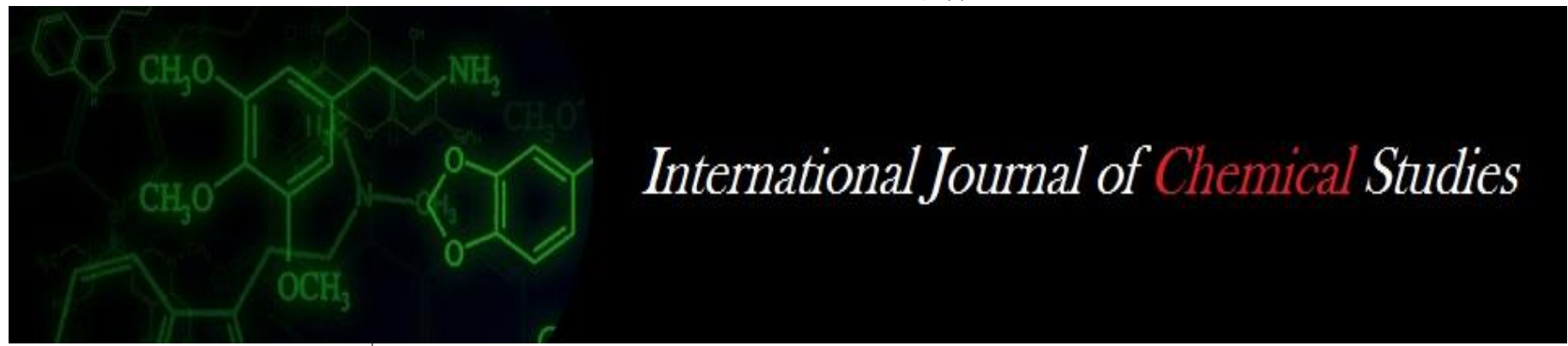

P-ISSN: 2349-8528

E-ISSN: 2321-4902

www.chemijournal.com

IJCS 2020; 8(3): 598-600

(C) 2020 IJCS

Received: 25-03-2020

Accepted: 27-04-2020

Sanghamitra Kalita

College of Veterinary Science,

Assam Agricultural University.

Khanapara, Guwahati, Assam,

India

Joga Dev Mahanta

College of Veterinary Science,

Assam Agricultural University.

Khanapara, Guwahati, Assam,

India

Deben Sapcota

College of Veterinary Science,

Assam Agricultural University.

Khanapara, Guwahati, Assam,

India

\section{Pankaj Deka}

College of Veterinary Science,

Assam Agricultural University.

Khanapara, Guwahati, Assam,

India
Corresponding Author: Sanghamitra Kalita

College of Veterinary Science,

Assam Agricultural University.

Khanapara, Guwahati, Assam,

India

\section{Microbiological profile of different sources of drinking water offered to commercial broiler chicken during monsoon season}

\author{
Sanghamitra Kalita, Joga Dev Mahanta, Deben Sapcota and Pankaj Deka
}

DOI: https://doi.org/10.22271/chemi.2020.v8.i3g.9275

\begin{abstract}
A study was carried out to investigate the effect of water from five different sources on the microbiological parameters of broiler chicken. Among the different sources, the total bacterial load was higher in pond water. However, after treatment, microbiological qualities (total viable count, total E. coli count and total coliform count) of all the sources of water under study were found to be reduced. The rain water was free from $E$. coli. The average total water consumption $(1 /$ bird $)$ of broiler chicken offered untreated pond water was lowest (12.055) and it was highest for bore well water (14.560). However, after treatment of water the total water consumption per bird increased numerically for all the groups. The overall water/ feed consumption ratio of broiler chicken offered different sources of water ranged from 3.67-4.07 wherein, it was lowest for untreated pond water (3.67) and highest for untreated rain water (4.07).
\end{abstract}

Keywords: Broiler chicken, E. coli, microorganism, water sources

\section{Introduction}

Water quality attributes can have a direct or indirect effect on the performance of broiler chicken. High level of bacterial contaminations, minerals or other pollutants in drinking water can have detrimental effects on normal physiological properties resulting in inferior performance (www.aces.edu). The drinking water may cause transmission of some bacterial, viral and protozoan infections that are among the most common poultry diseases. Water contaminated with microorganisms, algae, dust and rust is relatively common and can have a profound adverse impact on poultry performance. In some aspects, water quality can have a greater negative effect on performance of birds than feed quality because it is well known fact that birds consume more water than they consume feed. In modern era of poultry production water should be provided as clean as possible in order to avoid the possible microbial hazards. Good quality water is very important for good digestion and to create a healthy gut flora, which will help the bird to absorb all the essential nutrients and keep away the gut infections (Manwar et al., 2012a) ${ }^{[4]}$. Quality of surface and ground water depends upon the naturally occurring inclusions such as cations, anions, heavy metals and microorganisms. The main source of drinking water for humans as well as animals, by and large, is open wells or tube wells (Manwar et al., 2012b) ${ }^{[5]}$. The use of drinking water with high physical, chemical and microbiological qualities is of fundamental importance in animal production because many animals have access to the same water source and a problem in the water quality would affect a great number of animals. This is particularly related in poultry production, where one single water source serves thousands of animals. Therefore, control measures must be considered as priority, in order to prevent the occurrence of diseases that are spread through water, and would certainly result in great economic losses. Although water doesn't provide ideal conditions for pathogenic microorganisms to multiply, they will generally survive for enough time to allow waterborne transmission. Water is therefore, an excellent transmission route of agents responsible for human and animal diseases (Amaral, 2004) ${ }^{[1]}$. Most often, poultry farmers get alarmed only when the mortality level in a farm is high. However, even the existence of disease at a sub clinical level may hinder the performance of the birds, in terms of body weight or egg number. Such economic losses are sometimes relatively less and 
unnoticed, may mean the difference between success of failure in the poultry business. Hence, the adage "prevention is better than cure" applies more to poultry industry than any other field (Prabakaran, 2018) ${ }^{[6]}$.

\section{Materials and methods}

A total of 450 day-old commercial broiler chicks (Cobb 400) having similar body weight from a single hatch were procured from a local hatchery of Guwahati city. The chicks were weighed and randomly divided into ten experimental groups namely, untreated group with ring well water, treated group with ring well water, untreated group with tube well water, treated group with tube well water, untreated group with bore well water, treated group with bore well water, untreated group with pond water, treated group with pond water, untreated group with rain water and treated group with rain water. Further each group was again subdivided in 3 replicates containing 15 chicks in each group. The birds were offered both untreated and treated drinking water of these five sources. The treatment of water was done with the combination of acidifier and sanitizer at the rate each of 0.05 $\mathrm{ml}$ per liter of drinking water. water samples from all the untreated and treated groups were analysed for various physico-chemical parameters. The total viable count of bacteria in water samples was determined as per the method recommended by standard methods for the Examination of Water and Waste Water (1998). Pour plate method was used for the test. Serial tenfold dilution $\left(10^{-1}\right.$ to $\left.10^{-5}\right)$ of the water samples collected in sterile bottles was made in test tubes using normal saline solution as diluent. The diluent sample in $1 \mathrm{ml}$ volume was transferred into duplicate Petridis. About 15-20 ml of sterile molten plate count agar maintained at $45^{\circ}$ $\mathrm{C}$ was poured and mixed thoroughly with the inoculums. The plates were incubated at $37{ }^{\circ} \mathrm{C}$ for 24 hours. The plates which showed 30-300 colonies were selected and colonies were counted. Number of bacteria in the sample was determined by multiplying the mean of the colonies on duplicate plates with dilution factor which was expressed as colony forming unit $(\mathrm{CFU}) / \mathrm{ml}$ of the sample. Total E. coli in untreated and treated water samples was determined as per the method recommended by Standard method for the Examination of Water and Waste Water (1998) and it was done by spread plate method in Eosin Methylene Blue Agar (EMB agar). From the selected 10 -fold dilution, $0.1 \mathrm{ml}$ each of the inoculums was transferred into duplicate EMB agar plates. The inoculum was spread evenly using a sterile L-shaped disposable plastic rod and the plates were incubated at $37{ }^{\circ} \mathrm{C}$ for 24 hours. At the end of incubation, greenish black colonies with metallic sheen were counted as $E$. coli. The number of $E$. coli was estimated from mean CFU present in duplicate plates $\mathrm{x}$ dilution factor and was expressed as $\mathrm{CFU} / \mathrm{ml}$ of water sample.
Mac Conkey's Lactose bile broth was used and the medium after preparation was distributed in test tubes in $10 \mathrm{ml}$ volume with a Durham's tube placed in inverted position and tubes were autoclaved at $121{ }^{0} \mathrm{C}$ for 15 minutes. Five tubes system with each set consisting of five tubes was adopted as per the method recommended by Standard method for the Examination of Water and Waste Water (1998). In the $1^{\text {st }}$ set, each tube was inoculated with $10 \mathrm{ml}$ of sample, the $2^{\text {nd }}$ set with $1 \mathrm{ml}$ and the $3^{\text {rd }}$ set with $0.1 \mathrm{ml}$ of sample. The inoculated tubes were incubated at $37{ }^{\circ} \mathrm{C}$ for 24 hours. Acid and gas production was recorded as positive reaction. Numbers of tubes of each set with positive reaction was recorded and the results were compared with the table of Mac Conkey and the number of bacteria in $100 \mathrm{ml}$ of water was noted.

\section{Results and Discussion}

The average values of total viable count of bacteria $(\mathrm{cfu} / \mathrm{ml})$ of drinking water under different sources and treatment have been shown in Table 1

The average values of total viable count of bacteria $(\mathrm{cfu} / \mathrm{ml})$ of untreated ring well, tube well, bore well, pond and rain water were $190 \times 10^{3}, 21 \times 10^{3}, 170 \times 10^{3}, 207.20 \times 10^{3}, 0.73 \times 10^{2}$ respectively. The corresponding values for treated sources were $0.45 \times 10^{2}, 0.00,0.38 \times 10^{2}, 0.72 \times 10^{2}$ and 0.00 . Among the untreated sources highest total viable count of bacteria was found in pond water followed by ring well, bore well, tube well and rain water. In respect of treated sources, the total viable count of bacteria became nil in tube well and rain water. Due to treatment, the overall total viable count of bacteria reduced greatly for all the sources of water under study.

The total viable count is the measure of total number of viable bacteria in a sample of water. In the present study, the total bacterial count of all the untreated sources except rain water was very high as compared to the report of Thirunavukkarasu (1997) ${ }^{[8]}$, who found total bacterial count of $4428 \mathrm{cfu} / \mathrm{ml}$ and $164 \mathrm{cfu} / \mathrm{ml}$ in open and bore well water respectively in Namakkal taluk of Tamil Nadu. In another study, Abbas et al. (2010) reported that total bacterial count of Nile water in Egypt was uncountable as compared to the well water and commercial water. In support of the present findings, Ibitoye et al (2013) ${ }^{[3]}$ of Nigeria and Saidy et al. (2015) ${ }^{[7]}$ of Egypt also reported very high bacterial count in well water, farm tap water, farm stored water and underground water. The higher bacterial count in well water might be due to vulnerability to various pollutant and contamination by people fetching water from it (Ibitoye et al., 2013) ${ }^{[3]}$. The treatment of drinking water with the combination of acidifier and sanitizer greatly reduced the total bacterial count upto nil and his findings was in agreement with the report of Das (2013) ${ }^{[2]}$.

Table 1: Determination of Total Viable Counts of Bacteria, Total E. coli Count and total coliform Count by using MPN technique of broiler chickens under different sources and treatment of water

\begin{tabular}{|c|c|c|c|c|c|c|c|c|c|c|}
\hline \multirow[b]{2}{*}{ Parameter } & \multicolumn{2}{|c|}{ Ring Well } & \multicolumn{2}{|c|}{\begin{tabular}{|l|} 
Tube Well \\
\end{tabular}} & \multicolumn{2}{|c|}{ Bore Well } & \multicolumn{2}{|c|}{ Pond } & \multicolumn{2}{|c|}{ Rain } \\
\hline & Untreated & 1) Treated & Untreated & Treated & Untreated & Treated & Untreated & Treated & Untreated & Treated \\
\hline Total bacterial count $(\mathrm{cfu} / \mathrm{ml})$ & $190 \times 10^{3}$ & $0.45 \times 10^{2}$ & $21 \times 10^{3}$ & 0 & $170 \times 10^{3}$ & $0.38 \times 10^{2}$ & $207.20 \times 10^{3}$ & $0.72 \times 10^{2}$ & $0.73 \times 10^{2}$ & 0 \\
\hline Total E. coli count $(\mathrm{cfu} / \mathrm{ml})$ & $0.91 \times 10^{2}$ & 0 & $0.78 \times 10^{2}$ & 0 & $0.67 \times 10^{2}$ & 0 & $2.07 \times 10^{2}$ & $0.02 \times 10^{2}$ & 0 & 0 \\
\hline $\begin{array}{l}\text { Total coliform count by using MPN } \\
\text { technique (MPN index/100ml) }\end{array}$ & 1642 & $<2$ & 200 & $<2$ & 974 & $<2$ & 1462 & $<2$ & $<2$ & $<2$ \\
\hline
\end{tabular}




\section{Total $E$. coli count}

The average values of total $E$. coli count of drinking water of different sources and treatment have been shown in Table 1

The average values of total $E$. coli count $(\mathrm{cfu} / \mathrm{ml})$ of untreated ring well, tube well, bore well, pond and rain water was $0.91 \times 10^{2}, 0.78 \times 10^{2}, 0.67 \times 10^{2}, 2.07 \times 10^{2}$ and 0.00 respectively. The corresponding values for treated sources except pond water were nil. Among the untreated sources highest total $E$. coli count was found in pond water followed by ring well, tube well and bore well water.

E. coli is aerobic gram negative, motile rods, ferments lactose with production of gas and usually produces smooth, nonmucoid colonies on solid media. Its presence in water is an indication of fecal contamination. In the present study, untreated drinking water of different sources had an E. coli count of maximum $207 \mathrm{cfu} / \mathrm{ml}$. Contrary to the present findings Das (2013) ${ }^{[2]}$ and Ibitoye et al (2013) ${ }^{[3]}$ recorded lower E. coli count (cfu/ml) of 100 and 160 in ring well and pipe borne water respectively. On the other hand, Das et al (2011) ${ }^{[2]}$ found much higher $E$. coli count of $500 \mathrm{cfu} / \mathrm{ml}$ in water samples of west Bengal. The treatment of water with the combination of acidifier and sanitizer made the water free from $E$. coli except pond water $(2 \mathrm{cfu} / \mathrm{ml})$. The present findings corroborated with the report of Das (2013) ${ }^{[2]}$ who found zero $E$. coli in ring well water after treatment with the combination of acidifier and sanitizer.

\section{Total coliform count by using MPN technique}

The average values of total coliform count by using MPN technique of drinking water of different sources and treatment has been shown in Table 1

The average values of total coliform count by using MPN technique (MPN index/100 ml) of untreated ring well, tube well, bore well, pond and rain water was 1642, 200, 974, 1462 and $<2$ respectively. The corresponding values for all the sources of treated drinking water were $<2$. Among the untreated sources highest MPN INDEX per $100 \mathrm{ml}$ was found in ring well water followed by pond, bore well, tube well and rain water.

Coliform bacteria are gram negative, aerobic and non-sporing rods which ferments lactose with the formation of acid and gas within 24 hours at $37^{\circ} \mathrm{C}$. In the present study, the total coliform count of different sources of untreated water as per MPN technique ranged from < 2 to 1640 MPN index per 100 ml. Contrary to the present findings, Thirunavukkarasu (1997) ${ }^{[8]}$ found much higher level of coliform count of $2164 \mathrm{cfu} / \mathrm{ml}$ in open well water in Namakkal taluk of Tamil Nadu. In a similar study Saidy et al. (2015) ${ }^{[7]}$ reported the total coliform count of different sources of drinking water which ranged from 2.8 to $500 \mathrm{cfu} / \mathrm{ml}$. In contrary to the present findings, Abbas et al. (2010) revealed that coliform count was nil in different sources of water under their study. The total coliform count of untreated ring well water was reported as more than 1680 MPN index per $100 \mathrm{ml}$ (Das, 2013) ${ }^{[2]}$ which was comparable with the present findings (1640 MPN index per $100 \mathrm{ml}$ ) of untreated ring well water. In the present study, the total coliform count as per MPN technique was $<2$ per 100 $\mathrm{ml}$ in all the sources of drinking water treated with the combination of acidifier and sanitizer. This was in agreement with the report of Manwar et al. (2012b) ${ }^{[5]}$ and Das (2013) ${ }^{[2]}$, who also found the average total coliform count after treatment as <2 MPN index per $100 \mathrm{ml}$.

\section{References}

1. Amaral LA. Drinking water as a Risk factor to poultry health. Brazillian Journal of Poultry Science. ISSN 1516635X 2004; 6(4):191-199.

2. Das, Martina. Effect of Acidifier and sanitizer treated drinking water on the performance of broiler chicken. M.V.Sc. Thesis, College of Veterinary Science, Assam Agricultural University, Khaqnapara, Guwahati, Assam, 2013.

3. Ibitoye EB, Dabai YU, Mudi L. Evaluation of different drinking water sources in Sokoto North-West Nigeria on performance, carcass traits and haematology of broiler chickens. Veterinary World, 2013; 6(11):879-883.

4. Manwar SJ, Awandkar SP, Gaikwad NZ, Sardar VM. The Effect of acidifier and sanitizer treatment of drinking water on immune response and blood biochemistry in broiler chicks. Anim. Sci. Reporter. 2012a; 6(3):99-103.

5. Manwar SJ, Awandkar SP, Munde VK, Waskar VS. The effect of different sources of drinking water and commercially treated water on the performance of broiler chicken: Int. J Poult. Sci. 2012b; 47(1):60-63.

6. Prabakaran R. Water quality in Poultry Rearing. In: D. Sapcota, D Narahari and J.D. Mahanta (Ed) Avian (Poultry) Production, New India Publishing Agency, New Delhi, 2018, 239-242.

7. Saidy EL, N, Mohamed RA, Abouelenien F. Assessment of variable drinking water sources used in Egypt on broiler health and welfare. Vet World. 2015; 8(7):855864.

8. Thirunavukkarasu M. Quality of drinking water supplied from open and bore wells to layer farm in Namakkal Taluk. M.V.Sc Thesis, Tamil Nadu Veterinary and Animal Science University, Namakkal. 2nd Edn., International programme on Chemical Safety, Geneva. 1997, 2. 